\title{
(Des)Fazendo-se homem
}

Vidas de hombre(s).

GUASCH, Oscar (Org.). Barcelona: Edicions Bellaterra, 2012. p. 231.

Ainda que, muitas vezes no campo das ciências sociais, os estudos das relações de gênero sejam tomados como sinônimo de história das mulheres, nas últimas décadas, percebe-se a ampliação da utilização da perspectiva de gênero (pensada em sua transversalidade)' para a análise das experiências de outros sujeitos sociais. A incorporação do gênero pelos estudos LGBT (Lésbicas, Gays, Bissexuais, Travestis e Transexuais) e das masculinidades é um exemplo de que gênero é uma categoria útil de análise das experiências das mulheres, mas também dos homens, entre estes/as, aqueles/as que vivenciam feminilidades/masculinidades dissidentes: homossexuais, lésbicas, travestis e transexuais.

Nessa reinvenção teórica, escutam-se os ecos dos ensinamentos da historiadora Joan Scott, ${ }^{2}$ que lembra que o gênero se faz nas relações sociais, e, ainda, os protestos de teóricas/ os queer que enfatizam a necessidade de se pensar o gênero para além das categorias essencialistas e binárias, efeitos da revolução políitico-cultural iniciada pelo movimento feminista e seus desdobramentos nos movimentos LGBT e de homens pela igualdade.

A coletânea Vidas de hombre(s), organizada pelo sociólogo espanhol Oscar Guasch, insere-se nesse contexto de transformações politico-epistemológicas. O livro compõe o mosaíco das obras anteriores do autor dedicadas a analisar as mudanças sociais na história recente da Espanha, a partir de uma perspectiva de gênero e da Sociologia da Sexualidade. ${ }^{3}$

Em diálogo com a proposta do livro $Y$ no fueron marujas (2011), que reúne histórias de vida de mulheres que foram além das normas de gênero, Vidas de hombre(s) revisa criticamente as formas vigentes de ser homem a partir dos relatos autobiográficos dos autores - antropólogos, sociólogos, médicos, enfermeiros etc.

Os textos Historias edulcoradas de um superviviente com mal corazón (José Ángel Lozoya), Penitencia por "delito de género": relato sobre un adolescente afeminado (Laurentino
Vélez-Pelligrini), Um tipo (no tan) normal: masculinidades en/de tránsito (Jordi Roca Girona), En la cuerda floja (Fernando Sáez), Sobre Eros, homofobia y Baco (Oscar Guasch), Una pareja gay y su hijo, nuestra historia (Vicent Borràs), Las mujeres, mi lado femenino, y yo (Sergio Piñar), El jugador (de fútbol) (Alberto del Campo Tejedor), De aquí, de allí, de todos sitios (Eduardo Lizardo González), Una pareja no tan extraña (Toni y Àlvar) e Bajarse los pantalones (Miguel Ángel López Ramales) problematizam as seguintes questões: como cada autor se (des)fez homem? Que estratégias foram elaboradas como respostas às transformações de gênero?

Em meio à pluralidade de histórias, tecidas a partir de narrativas de homens heterossexuais e homossexuais, encontram-se pontos em comum na constituição das memórias (masculinidades) subalternas, limítrofes e dissidentes.

Trata-se de vidas (e textos) marcadas, na infância, pelo nacional catolicismo do regime franquista, cujo dispositivo da culpa/repressão atingia, principalmente, mas, não apenas, os meninos afeminados. Os textos dos antropólogos Vélez-Pelligrini, Girona e Guasch são ilustrativos dos efeitos da violência homofóbica da qual foram vítimas os meninos (os autores) acusados de "delito de gênero".

O encontro com o pensamento/movimento feminista aparece nas reminiscências dos autores como outro acontecimento partilhado. Lozoya e Ramales lembram as descobertas do encontro com as mulheres feministas, que, ao final, contribuiu para a participação destes no movimento de homens pela igualdade. Tal encontro possibilitou aos autores a elaboração de ferramentas teórico-politicas de crítica ao regime machista, que, além de violentar mulheres e homossexuais, violenta também aqueles homens heterossexuais que não seguem as normas estabelecidas pela masculinidade hegemônica.

O envolvimento com os movimentos sociais (feministas, homossexuais, homens pela igualdade) e a escolha de temas relacionados às sexualidades como objeto de estudo aparecem como estratégias de superação dos traumas e das feridas da infância/adolescência narrados de modo honesto e emocionante pelos autores.

A essas experiências partilhadas, cruzamse memórias singulares marcadas pela fome, pelo medo, pela culpa, pelos jogos eróticos, pela relação conflituosa com o pai; memórias 
afetivas que reservam aos/as companheiros/as dos autores um lugar privilegiado. Os relatos de Vicent Borràs sobre os desafios enfrentados ao lado do seu companheiro Jordi para adotar um filho; de Fernando Sáez, que, ao se casar com uma mulher mais velha, desviou-se da masculinidade hegemônica; e de Tony e Àlvar, homossexuais que estão juntos há mais de três décadas, misturam histórias de amor e de esperança às outras de medo, culpa e violências.

Estranhamente, Vida de hombre(s) não incorpora, em seus relatos, histórias de transhomens, ${ }^{4}$ cujas experiências e reinvindicações têm colaborado para desfazer o binarismo/essencialismo dos gêneros e a naturalidade da categoria homem. Certamente, essa estranha ausência não está relacionada à filiação dos autores ao entendimento da masculinidade como algo natural pertencente aos "homens de verdade". Essa hipótese é recusada nas primeiras páginas do livro em detrimento do pensamento que compreende a masculinidade a partir de estratégias de "reforma" - ser homem é uma construção cultural que necessita ser transformada - e de "renúncia", que, mais do que reformada, necessita ser negada. Tal ausência também não se explica pela invisibilidade de transhomens na Espanha, país de origem dos autores que compõem a coletânea. Lembremos, por exemplo, de Miquel Missé, sociólogo e ativista trans de Barcelona, membro da luta pela despatologização trans e da campanha STP2012. Contudo, nos concentremos nas presenças.

A leitura da coletânea organizada por Guasch é um convite a pensarmos a multiplicidade dos gêneros (e o perigo das identidades essencialistas); o conhecimento como ferramenta de crítica e de transformação social; outras memórias, menos marcadas por violências e exclusões; e outras histórias, nas quais os homens - inscritos de modo universal e hegemônico na História - sejam liberados da obrigação e da prisão de ser Homem.

Vida de hombre(s) nos revela que, diante das transformações contemporâneas (conquistas feministas e da comunidade LGBT, por exemplo), o potencial social e de crítica do gênero segue relevante, uma vez que a sociedade, inclusive uma parte significativa dos/as pesquisadores/as, ainda pensa o gênero em seus limites binários, essencialistas e heteronormativos.

\section{Notas}

1 Para saber mais sobre as relações de gênero como categoria transversal na historiografia contemporânea ver Joana Maria PEDRO, 2011.

${ }^{2}$ Joan SCOI, 1990.

${ }^{3}$ A trilogia da sexualidade composta pelos livros La sociedade rosa, La crisis de la heterosexualidad e Héroes, científicos, heterosexuales y gays oferece um panorama significativo das preocupações teóricas de Guasch.

${ }^{4}$ De acordo com as pesquisadoras Simone ÁVILA e Miriam GROSSI, 2013, transhomens são pessoas trans que se identificam com o gênero masculino e que não necessariamente participam de programas de readequação sexual (ou readequação de gênero) ou se submetem a intervenções cirúrgicas.

\section{Referências}

AVILA, Simone; GROSSI, Miriam. "O 'y' em questão: as transmasculinidades brasileiras". In: SEMINÁRIO INTERNACIONAL FAZENDO GÊNERO, 10., 2013, Florianópolis. Anais eletrônicos... Florianópolis: UFSC, 2013. Disponível em: <http://www.fazendogenero. ufsc.br/10/resources/anais/20/ 1386768141 ARQUIVO SimoneAvila.pdf $>$. Acesso em: 28 de maio de 2014.

GUASCH, Oscar. Héroes, científicos, heterosexuales y gays: los varones en perspectiva de género. Barcelona: Bellaterra, 2006.

La crisis de la heterosexualidad. Barcelona: Laertes, 2000.

- La sociedad rosa. Barcelona, Anagrama 1991.

MISSÉ, M.; COLL-PLANAS, G. (Ed.). El género desordenado. Críticas en torno a la patologización de la transexualidad. Barcelona; Madrid: Egales, 2010.

MISSÉ, M. Transexualidades. Otras miradas posibles. Barcelona; Madrid: Egales, 2013.

PEDRO, Joana Maria. "Relações de gênero como categoria transversal na historiografia contemporânea". Topoi, Rio de Janeiro, v. 12, n. 22, p. 270-283, jan./jun. 2011.

SCOTT, Joan. "Gênero, uma categoria útil de análise histórica". Educação e Realidade, Porto Alegre, v. 16, n. 2, p. 5-22, jul./dez. 1990.

Elias Ferreira Veras

Universidade Federal de Santa Catarina 